\title{
PERCEPTIONS OF ADULTS WITH SPINAL CORD INJURY ON THE SKILLS FOR DAILY ACTIVITIES AND HEALTH INDICATORS IN THE LIGHT OF NOC: DESCRIPTIVE RESEARCH
}

\author{
Inacia Sátiro Xavier de França1, Alexsandro Silva Coura2, Ana Paula Andrade \\ Ramos3, Cibely Freire de Oliveira4, Francisco Stélio de Sousa5
}

\author{
$1,3,4,5$ Universidade State of Paraiba \\ 2Federal University of Rio Grande do Norte
}

\begin{abstract}
Objective: Verify the perception of adults with spinal cord injury (SCI) on their skills for daily activities and pair data with health indicators in the light of NOC. Method: Cross-sectional study, census and quantitative, conducted in 2008 in UBSF's Campina Grande-PB. 47 people have taken part as sample, who answered a form with indicators domain of the Functional Health of NOC and an Questionnaire A, composed by questions about abilities to perform daily activities. It was performed a pairing between the instruments and used the SPSS to analyze data. Results: Cronbach Alpha was 0.752. The items that showed more commitment were: Management of money $(80.8 \%)$, sexual performance $(74 \%)$, Leisure $(68 \%)$, Labor $(55 \%)$ and ambulation $(45 \%)-p<0.001$. Conclusion: There is impairment on the participants' skills for daily activities. Nurses can help them develop actions of health education and research that contribute to improving public policies for those people.
\end{abstract}

Descriptors: Nursing; Disabled Persons; Activities of Daily Living

\section{INTRODUCTION}

Currently, the incidence of Spinal Cord Injury (SCI) is becoming, around the world, a public health issue due to the growth of episodes of urban violence, such as traffic accidents and assaults with firearms ${ }^{(1)}$ and due to the occurrence of neoplastic, viral and bacterial diseases that can intervene in the nerve pathways that connect the brain and muscles ${ }^{(2) .}$

A review, considering the data available around the world, pointed to prevalence rates ranging from 2.23 to 7.55 per 10,000 people and an incidence between 10.4 and 83 per million inhabitants per year ${ }^{(3)}$. In the year $2007,832,858$ users were treated in the health services of Brazil because of external injuries, a relevant number, since the traumatic SCI is the most frequent one ${ }^{(4)}$.

The spinal cord acts as a pathway that communicates brain and various parts of the body, besides being an important regulator centre that controls important functions such as breathing, circulation, urinary and bowel elimination, sexual activity, thermal management and skeletal muscle ${ }^{(5)}$. Thus, an injury in this organ can have serious consequences for those affected, such as deficiencies in the listed functions, and body aches.

Algesic processes ${ }^{(6)}$, the lack of movement due to motor limitations, as well as architectural and attitudinal barriers faced by people with SCI are primarily responsible for the difficulties faced by these individuals to perform activities of daily living (ADLs).

This inability to ADLs in adults with SCI increases their vulnerability to addiction and the risks of more serious health problems. From this perspective, this social segment has specific needs that require specialized long-lasting healthcare ${ }^{(7)}$.

Online braz. J. nurs. (Online); 10(2) abr-ago. 2011. 
In this context, the therapeutic actions of rehabilitation, during and after the acute SCI period, are important because it helps affected patients to improve skills in order to perform ADLs and implement effective self-care. Studies show that 70 to $80 \%$ of people with a complete spinal cord injury with motor power of grade 1 to 2, recover the next neurological level between 3 and 6 months $^{(8)}$. The inclusion in rehabilitation activities means more than the possibility of regression of neurological deficit. It is also linked to the prospect of improvement in ADLs, the decrease in the degree of dependence on carers, improvement in social interaction, the reduction of clinical comorbidities resulting from long periods in bed and, lastly, improvement in quality of life.

An instrument that can be used by nurses in rehabilitation assistance for people with SCI is the Nursing Outcomes Classification (NOC). Its taxonomy is applicable to individuals, families and communities to describe a state, behaviour or perception at a given time, anywhere on the continuum, be it positive or negative. The listed results in the NOC contain indicators that can be used by nurses, allowing a selection of those relevant according to the situation ${ }^{(9)}$. From this perspective, the study's objective is to verify the perception of adults with SCI on their daily activities and to compare the data with health indicators in the light of the NOC. Besides being related to a serious public health issue, the relevance of the study is indicated by the possibility to produce knowledge for academic purposes since it enriches its collection with deeper information that will serve as a source of research and provide material to improve nurse training in order to plan a better nursing rehabilitation care system. It aims at ensuring better health and quality of life for people living with SCI and contributes to the formation of other professionals working in healthcare rehabilitation programs. Furthermore, this study has the potential to generate social impact, indicating points that might stimulate public policies for the disable, so as to minimize the difficulties in (re) inclusion of these people.

\section{METHODOLOGY}

It is a cross-sectional quantitative census study conducted in 2008 in the Family Health Basic Units (FHBU's) in Campina Grande-PB. The project was approved by the Ethics Committee of Research of University of Paraiba (UEPB), Protocol $n^{\circ}$ 0228.0.133.000-07. The ethical principles laid out in Resolution No.196/96 of the National Health were fully respected.

The population considered in this study was all the SCI sufferers registered with the FHBU's of Campina Grande city. A population census was conducted, which allowed the participation of 47 individuals with SCI, of both genders, urban dwellers, over 18 years old, enrolled in one of the 61 existing FHBU's, who have been subjected to some therapeutic action of rehabilitation at least six months before.

Two instruments were used: 1) A form with the Functional Health Domain indicators proposed by NOC, containing the Results: a) Self-Care: Activities of Daily Living (ADLs) that corresponds to the ability to perform daily tasks. b) Self-care: Instrumental Activities of Daily Living (IADLs) that refers to the ability to perform household tasks or activities in the community ${ }^{(9)}$, Online braz. J. nurs. (Online); 10(2) abr-ago. 2011. 
2) a questionnaire $A$ formulated by the researchers, consisting of questions about the skills: the ability to manage money; use public transportation; carry out daily activities, leisure, sexual activity; do what is necessary despite pain; feed, dress and bathe themselves; use a wheelchair and perform wheelchair transfer. For this instrument, the question was: To what extent do you think you have the skills to perform tasks of daily living? These two instruments were measured using Likert-type scales, ranging from 1 to 5 , considering, for the NOC, the health condition impairment and, for the questionnaire $A$, aid dependence. The correlation between the scores of these instruments' indicators was established, as shown in Table 1.

\begin{tabular}{|c|c|c|c|c|}
\hline \multicolumn{5}{|c|}{ The instruments' indicators correlation } \\
\hline Instruments & Correlation A & Correlation B & Correlation C & Correlation D Correlation E \\
\hline \multirow[t]{2}{*}{ NOC } & Extremely & Substantially & Moderately & \multirow{2}{*}{$\begin{array}{l}\text { Slightly } \\
\text { Impaired }\end{array}$} \\
\hline & Impaired & Impaired & Impaired & \\
\hline \multirow{4}{*}{$\begin{array}{l}\text { Questionnaire } \\
\text { A }\end{array}$} & \multirow{4}{*}{$\begin{array}{l}\text { Dependent, } \\
\text { don't } \\
\text { participate }\end{array}$} & \multicolumn{2}{|c|}{ Need assistant Need } & Independent, Completely \\
\hline & & and help & f assistant & with the help independent \\
\hline & & auxiliary & & of auxiliary \\
\hline & & mechanism & & mechanism \\
\hline Scores & 1 & 2 & 3 & 4 \\
\hline
\end{tabular}

Initially, for data collection, the researcher identified people with SCI in the FHBU's. Then, accompanied by the community health worker responsible for the area, they paid home visits to the sufferers. After explaining about the research and having a consent form signed, the instruments were applied and the interviewer placed an $\mathrm{X}$ on the Likert scales according to participants' responses. Data were processed using the Statistical Package for the Social Sciences (SPSS), Windows operating system, version 14.0, and displayed in cross tables, enabling the analysis of the relation between Questionnaire A and the NOC indicators. The absolute and simple frequencies were calculated and the chi-square test $\left(\chi^{2}\right)$ performed to compare the scale proportions with the data matched, being considered statistically significant $\mathrm{p}<0.05$.

The Cronbach's alpha test was used to check the Questionnaire A's internal consistency, considering the values of the Item-Total Correlation, Cronbach's Alpha with Item Deleted and Total Cronbach's Alpha.

\section{RESULTS}

\section{Gender and age}


43 men and four women with an average age of 42.95 years old, under 73 years old, over 19 years old, and standard deviation of \pm 14.12 took part in the study. The internal consistency of the Questionnaire A

The internal consistency of the Questionnaire A was verified as shown in Table 1, which indicates that the Total Cronbach's Alpha's value was of 0.752 . The reliability of the instrument can also be provided by the acceptable values when each item deleted was considered.

Table 2 - Questionnaire A tested with total Cronbach's Alpha, total Correlation of corrected items and Alpha with item deleted.

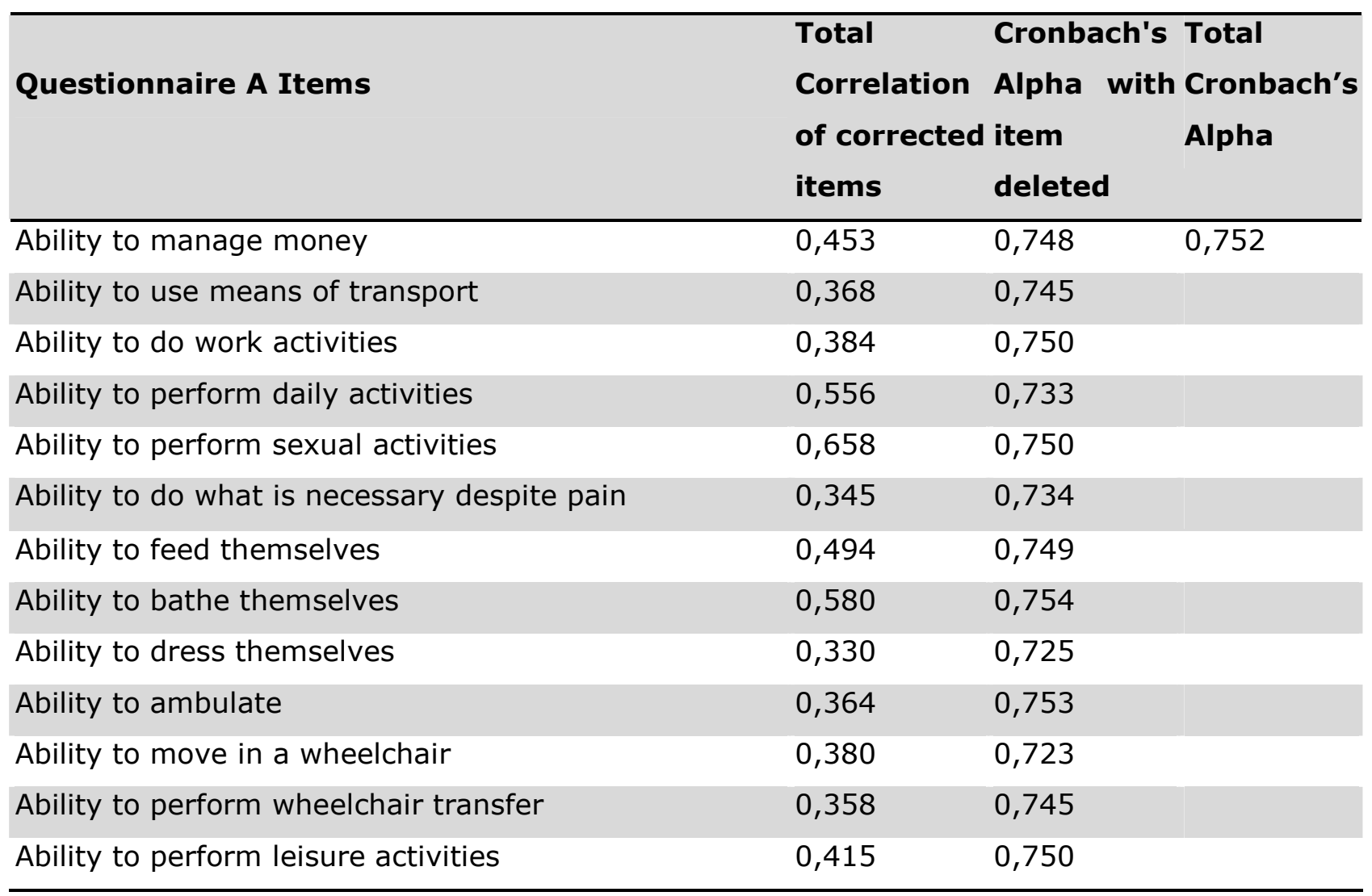

Source: Research data.

\section{Perception on the skills for the Instrumental Activities of Daily Living}

The items that showed greater impairment (extremely or substantially) were: money management $(80.8 \%)$, sexual performance $(74 \%)$ and work $(55 \%)$. On the other hand, lower impairment (slight or no impairment) were: use of public transport (38.3\%), pain (30\%) and performance of household tasks (35\%).

Table 3 - Distribution of individuals with SCI according to the paired indicators and the Instrumental Activities of Daily Living, Campina Grande-PB, 2008.

\begin{tabular}{|c|c|c|c|c|c|c|c|c|c|c|c|}
\hline \multicolumn{2}{|c|}{ Paired Indicators } & \multicolumn{2}{|c|}{$E C=1$} & \multicolumn{2}{|c|}{ SC $=2$} & \multicolumn{2}{|c|}{$M C=3$} & \multicolumn{2}{|c|}{$L C=4$} & \multicolumn{2}{|c|}{ NC $=5$} \\
\hline NOC & Questionnaire A & $\mathbf{n}$ & $\%$ & $\mathbf{N}$ & $\%$ & $\mathbf{n}$ & $\%$ & $\mathbf{n}$ & $\%$ & $\mathbf{n}$ & $\%$ \\
\hline Mar & $\begin{array}{ll}\text { Ability to mar } \\
\text { money and ha }\end{array}$ & & 10,6 & 33 & 70,2 & 6 & 12,8 & 3 & 6,4 & 0 & 0,0 \\
\hline
\end{tabular}

Online braz. J. nurs. (Online); 10(2) abr-ago. 2011. 
the needs met

\begin{tabular}{|c|c|c|c|c|c|c|c|}
\hline $\begin{array}{l}\text { Use public } \\
\text { transportation }\end{array}$ & $\begin{array}{l}\text { Ability to use means } 8 \\
\text { of transport }\end{array}$ & $17,0 \quad 14$ & 29,8 & & $14,9 \quad 13$ & 27,75 & 10,6 \\
\hline Work & $\begin{array}{l}\text { Ability to do work } 14 \\
\text { activities }\end{array}$ & $30,0 \quad 12$ & 25,0 & 11 & 23,07 & 15,03 & 7,0 \\
\hline $\begin{array}{l}\text { Perform } \\
\text { household } \\
\text { tasks }\end{array}$ & $\begin{array}{l}\text { Ability to perform } 9 \\
\text { daily activities }\end{array}$ & $19,0 \quad 11$ & 23,0 & 11 & $23,0 \quad 13$ & 28,03 & 7,0 \\
\hline $\begin{array}{l}\text { Sexual } \\
\text { performance }\end{array}$ & $\begin{array}{l}\text { Ability to perform } 16 \\
\text { sexual activities }\end{array}$ & 34,019 & 40,0 & 7 & 15,05 & 11,00 & 0,0 \\
\hline Pain & $\begin{array}{l}\text { Ability to do what is } 6 \\
\text { necessary despite } \\
\text { pain (physical) }\end{array}$ & $13,0 \quad 13$ & 27,0 & 14 & 30,09 & 19,05 & 11 \\
\hline
\end{tabular}

Source: Research data. $\mathrm{n}=47 ; \chi 220 \mathrm{GL}=55.44 ; \mathrm{p}<0.001 ; \mathrm{EI}=$ Extremely impaired; $\mathrm{SI}=$ Substantially impaired; $\mathrm{MI}=$ moderately impaired; $\mathrm{SI}=$ slightly impaired and $\mathrm{NI}=$ Not impaired.

\section{Perception on the skills for the Instrumental Activities of Daily Living}

There was greater impairment (extremely or substantially) in the following items: leisure $(68 \%)$ and ambulation (45\%). Lower impairment (light or no impairment) were: ability to perform wheelchair transfer $(91 \%)$, bathing $(83 \%)$, dressing $(81 \%)$, feeding $(76.6 \%)$ and moving on a wheelchair (72\%).

Table 4 - Distribution of individuals with SCI according to the paired indicators and Activities of Daily Living, Campina Grande-PB, 2008.

\begin{tabular}{|c|c|c|c|c|c|c|c|c|c|c|c|}
\hline \multicolumn{2}{|c|}{ Paired Indicators } & \multicolumn{2}{|c|}{$E C=1$} & \multicolumn{2}{|c|}{ SC $=2$} & \multicolumn{2}{|c|}{$M C=3$} & \multicolumn{2}{|c|}{ LC $=4$} & \multicolumn{2}{|c|}{ NC $=5$} \\
\hline NOC & Questionnaire A & $\mathbf{n}$ & $\%$ & $\mathbf{N}$ & $\%$ & $\mathbf{n}$ & $\%$ & $\mathbf{n}$ & $\%$ & $\mathbf{n}$ & $\%$ \\
\hline Feeding & $\begin{array}{l}\text { Ability to feed } \\
\text { themselves }\end{array}$ & & 4,3 & 2 & 4,3 & 7 & 14,8 & 9 & 19,1 & 27 & 57,5 \\
\hline Bathing & $\begin{array}{l}\text { Ability to bathe } \\
\text { themselves }\end{array}$ & & 0,0 & 0 & 0 & 8 & 17,0 & 23 & 49,0 & 16 & 34,5 \\
\hline Dressing & $\begin{array}{l}\text { Ability to dress } \\
\text { themselves }\end{array}$ & & 0,0 & 0 & 0 & 9 & 19,0 & 23 & 49,0 & 15 & 32,0 \\
\hline Ambulation & $\begin{array}{l}\text { Ability to ambulate on } \\
\text { their own }\end{array}$ & 12 & 26,0 & 09 & 19 & 23 & 49,0 & 03 & 6,0 & 0 & 0,0 \\
\hline $\begin{array}{l}\text { Movement: } \\
\text { on } \\
\text { wheelchair }\end{array}$ & $\begin{array}{l}\text { Ability to move on } \\
\text { a wheelchair }\end{array}$ & & 9,0 & 0 & 0 & 9 & 19,0 & 16 & 34,0 & 18 & 38,0 \\
\hline Performance & Ability to perform & 04 & 9,0 & 0 & 0 & 0 & 0,0 & 25 & 53,0 & 18 & 38,0 \\
\hline
\end{tabular}


wheelchair

transfer

Leisure

$\begin{array}{lllllllllll}\text { Ability to perform } 14 & 30,0 & 18 & 38 & 12 & 26,0 & 1 & 2,0 & 2 & 4\end{array}$

leisure activities

Source: Research data. $\mathrm{n}=47 ; \chi 220 \mathrm{GL}=218,6 ; \mathrm{p}<0,001 ; \mathrm{EI}=$ Extremely impaired;

$\mathrm{SI}=$ Substantially impaired; $\mathrm{MI}=$ moderately impaired; SI = slightly impaired and

$\mathrm{NI}=$ Not impaired.

\section{DISCUSSION}

The highest proportion of male subjects was also observed in other national ${ }^{(10-11)}$ and international $^{(12)}$ studies. In a survey conducted in Fortaleza ${ }^{(10)}$, there was a frequency of $96.6 \%$ of men amongst the SCI sufferers. In a study ${ }^{(12)}$ in the region of Arizona, United States, $82 \%$ of SCI sufferers were male.

The inability to manage money in order to meet the needs found in this study may be due to low-income, feature identified in research ${ }^{(11)}$ developed in the Sarah Hospital in Brasilia that investigated life quality of $108 \mathrm{SCI}$ sufferers and found that the lack of financial resources has the most overt impact on their quality of life.

Work, an indicator directly related to income, was impaired in the perception of participants. This finding confirms another study ${ }^{(10)}$ that identified social domain as the most impaired in a group of people who have suffered SCI. However, different from the result of another study ${ }^{(12)}$, conducted in the United States, which concluded that: a) the likelihood of employment after SCI varies among individuals, and, b) that the favorable characteristics of employability are better than previous estimates.

As can be seen, the differences between developed and developing countries should be considered in regard to the problems of people with SCI. In this sense, in a systematic review of the literature focusing on health services access for disabled people, the authors ${ }^{(13)}$ concluded that public policies in Brazil and in other developing countries should be based on Bioethics Protection (the State protecting the most vulnerable in a collectively way), while developed nations should use Principialism (principles that are applied individually).

Concerning the Sexual Performance Indicator, participants reported negative perception exemplified by: motor deficit, reflex erection and difficulty and / or absence of ejaculation. In a study conducted in São Paulo with the aim of identifying nursing diagnoses, according to NANDA, with SCI patients of Unit of Orthopedics and Traumatology, it was found that sexual dysfunction was present in $80 \%$ of the patients studied and $100 \%$ of the patients had the defining characteristics: inability to achieve the desired satisfaction and verbalization of the problem $^{(14)}$.

In terms of Leisure, the high frequency of people who complained of some degree of impairment is worrying, since, in addition to the physical limitations, these individuals also face Online braz. J. nurs. (Online); 10(2) abr-ago. 2011. 
architectural barriers and difficulty in accessing public transportation because they are not always adapted to this social group. Moreover, economic hardship, prejudice and self prejudice are responsible for impairing the fulfillment of the need for leisure.

Regarding ambulation, the impairment of this function may be related to lack of balance in orthostatic position and ambulation intolerance to distances greater than 50 meters. This finding is reported in another study with SCI sufferers, in which nurses instructions to treat the impaired physical mobility are associated with the prevention and treatment of potential complications such as deep vein thrombosis and pressure ulcers ${ }^{(15)}$. The impaired physical mobility may trigger other conditions that worsen health, aggravating some symptoms that require hospitalization and make the SCI sufferer more aid dependent.

It's been demonstrated the considerable impairment of physical and social aspects, however an integrative ${ }^{(15)}$ study review that aimed to identify nursing interventions used in health care for SCI sufferers in pre hospital, hospital or domiciliary care, found that most of nursing interventions aimed at solving physical problems at the expense of subjective ones.

\section{IMPLICATIONS FOR NURSING}

There is, in the nursing field, a lack of knowledge in regard to validated instruments that have the potential to measure the SCI sufferers' ability to do everyday activities. The literature ${ }^{(13)}$ shows that the basic needs of disabled people (DP) are protected by law which guarantees the enjoyment of legal rights in order to meet their needs in the various aspects of life, however these rights are still not fully respected. It is believed to be necessary to implement specific care to SCI sufferers, preventing them from receiving the same assistance offered to those without disabilities, ignoring their specificities. And despite the evidences of gradual growth of studies related to SCI sufferers, it is still necessary to encourage research and development of strategies and decision making on DP's health. In this context, it is suggested that technological development in the area be encouraged, taking into account the peculiarities that SCI care requires.

It is recommended that nursing care should be implemented in a systematic and holistic manner, considering people with SCI in a comprehensive way, so that physical, social, environmental and subjective needs are addressed. From this perspective, possible strategies to add quality to nursing care for people with spinal cord injury need to ensure: inclusion, in the healthcare courses curriculum, of components that addresses the implications of the International Classification of Functioning and Disability elements, developed by the World Health Organization; participation of health professionals in an interdisciplinary team focused on systematization of humanitarian assistance, solidarity and citizenship. It's important that the professionals help SCI sufferers to recognize the limitations of their body and train them to acquire skills to perform activities of daily living. The primary care professionals should value the home visit as a means of promoting health education for SCI sufferers and their families so that they could learn how to prevent skin complications, such as pressure ulcers, osteoarticular, nefrourologic, digestive, circulatory and respiratory complications. It is Online braz. J. nurs. (Online); 10(2) abr-ago. 2011. 
imperative that nurses should learn how to make assertive decisions in situations that require referral, evaluation and interference of other health professionals. For an expanded assistance, it is necessary that professionals develop actions aimed at raising community awareness about the SCI sufferers' need for health services access, education, employment, tourism and leisure. It's also important to develop supportive social networks committed to the reduction of architectural and attitudinal barriers, and the development of social and emotional interactions that contributes to the inclusion of SCI sufferers in society.

\section{CONCLUSION}

The SCI sufferers' perception on their skills for daily activities is not good because of the items Money Management, Sexual Performance, Work, Leisure and Ambulation represent great impairment.

The conclusion is that nurses can contribute to improving the DP's quality of life through home care focused on health education and studies that expand knowledge about this subject and support improvement of public policies on this social sector. It is recommended that rehabilitation nurses invest in publications that focus on their practices in order to give greater visibility to the demands of people with SCI and the relevance of nursing interventions at all levels of complexity of assistance.

\section{REFERENCES}

1. Cavalcante KMH, Carvalho ZMF, Barbosa IV, Rolim GA. Vivência da sexualidade por pessoas com lesão medular. Rev. RENE. Fortaleza, 2008; 9(1): 27-35.

2. Blanes L, Carmagnani MIS, Ferreira LM. Quality of life and self-esteen of persons with paraplegia living in São Paulo, Brazil. Qual Life Res. 2008; 18(1): 15-21.

3. Wyndaele M, Wyndaele JJ. Spinal Cord. Epub 2006 Jan 3; Incidence, prevalence and epidemiology of spinal cord injury: what learns a worldwide literature survey. 2006; 44(9): 523-9.

4. Ministério da Saúde (Brasil), DATASUS: Indicadores e Dados Básicos Brasil 2008. [online] 2008; [citado 2009 out 12]. Disponível em: <http://www.datasus.gov.br>.

5. Benavent A, Pelazon R, Tamayo R, et al. Assessment of disability in spinal cord injury. Disabil Rehabil. 2003; (25): 1065-70.

6. Ninomya AF. Análise clínica e ultrassonográfica dos ombros de pacientes lesados medulares em programa de reabilitação. Acta ortop. bras. 2007; 15(2) Disponível em: http://www.scielo.br/scielo.php?script=sci_arttext\&pid=S141378522007000200011\&nr $\mathrm{m}=$ iso\&tlng=pt. Acessado em: 13 de out de 2007

7. Haddad S, Silva PRS, Pereira BAC, et al. Efeito do treinamento físico de membros superiores aeróbio de curta duração no deficiente físico com hipertensão leve. Arq. Bras. Cardiol. 1997; set; 69(3): 169-73

8. Ditunno JF. Burns AS, Marino RJ. Neurological and functional capacity outcome measures: Essential to spinal cord injury clinical trials. Journal of Rehabilitation Research \& Development. 2005; may-jun 42(3): 35-42. Available from: http://www.rehab.research.va.gov/jour/05/42/3suppl1/ditunno.html

9. Johnson, M. Classificação dos resultados de enfermagem. Porto Alegre: Artmed; 2004.

Online braz. J. nurs. (Online); 10(2) abr-ago. 2011. 
10. Vall J, Braga VAB, Almeida PC. Estudo da qualidade de vida em pessoas com lesão medular traumática. Arq Neuropsiquiatr. 2006; 64 (2-B): 451-5.

11. Bampi LNS, Guilhem D, Lima DD. Qualidade de vida em pessoas com lesão medular traumática: um estudo com o WHOQOL-bref. Rev Bras Epidemiol. 2008; 11(1): 67-77.

12. Pflaum C, McCollister G, Strauss DJ, Shavelle RM, DeVivo MJ. Worklife After Traumatic Spinal Cord Injury. J Spinal Cord Med. [on-line]. 2006; [Access: $2011 \mathrm{fev}$ 22]; 29 (4): 377-86.

13. França ISX, Coura AS, França EG, Cavalcante GMC, Sousa FS. Application of principlist bioethics to public policies for disabled people: systematic review. Online Brazilian Journal of Nursing [online] 2010; [Access: 2011 mar 11]; 9 (1). Available from: http://www.objnursing.uff.br/index.php/nursing/article/view/2893

14. Cafer CR, Barros ALBL, Lucena AF, Mahl MLS, Michel JLM. Diagnósticos de enfermagem e proposta de intervenções para pacientes com lesão medular. Acta Paul Enferm. 2005; 18 (4): 347-53.

15. Vasconcelos AS, França ISX, Coura AS, Sousa FS, Souto RQS, Cartaxo HGO. Nursing interventions on the needs of people with spinal cord injury: an integrative review. Online Brazilian Journal of Nursing [online]. 2010; [Access: 2011 mar 10]; 9(2) Available from: http://www.objnursing.uff.br/index.php/nursing/article/view/j.1676$\underline{4285.2010 .3000 / 674}$

\section{PARTICIPAÇÃO DOS AUTORES NA PESQUISA}

Inacia Sátiro Xavier de França foi responsável pela concepção do projeto de pesquisa e revisão crítica;

Alexsandro Silva Coura, pela análise e interpretação dos dados;

Ana Paula de Andrade Ramos, pela análise e interpretação dos dados;

Cibely Freire de Oliveira, pela análise e interpretação dos dados;

Francisco Stélio de Sousa, pela redação e revisão crítica. 